\title{
Convalescence from Modernity: Writing Assessment in the Epoch of Scientism
}

\section{Anthony Petruzzi}

\begin{abstract}
While some argue that post-modernity has overcome the era of modernity, claiming a rupture from previous ways of thinking and acting, reports of the 'death of modernity' have been greatly exaggerated. Its tenets continue to order and constitute valuestransmitted by cultural dispositions-and frame North American conversations about assessment, technology, and educational methodology. The governing philosophical assumption of writing assessment theory is scientism. It is a modernist prejudice, which is unseen and unquestioned, that assumes scientific thinking is the best-the "strongest" thinking-because it produces quantified, generalized, reliable, and true information.
\end{abstract}

To convalesce from modernity, we must continue to weaken the implicit and explicit cultural dispositions that transparently structure assessment practices. We have failed to persuade stakeholders that we should assess cognitively complex performances, which require hermeneutic interpretation to evaluate students' deep understandings and our programs' effectiveness.

A postmodern disposition allows us to recover a balanced view of the benefits that scientific practices give us. We can convalesce from the quest for certainty, the fear of subjectivity, and the discourse of technology, and develop a healthier disposition regarding both the power and usefulness of science. Such a recovery would create new dispositions to accept probable truths as events within historical horizons and to assess intellectual activity - how students use and apply knowledge. Only a retrieval of the irreducible complexity of student learning and writing will create the context to revise the practice and theory of educational assessment.

\section{Key words \\ writing and educational assessment theories, Canadian writing assessment, consequences of modernity, discourse of technology, accountability}

\section{Résumé}

Bien que certains soutiennent que la postmodernité ait supplanté la modernité en affirmant qu'il y a une rupture par rapport aux modes de penser et d'agir du passé, il est prématuré de parler de « mort de la modernité ». En effet, les principes modernistes continuent à former et ordonner les valeurs transmises dans la culture, sous-tendant les conversations en Amérique du Nord sur l'évaluation, la technologie et les méthodes d'enseignement. À ce titre, la philosophie principale utilisée pour la théorie sur l'évaluation de l'écriture est le scientisme. Ce dernier est une approche moderniste, acceptée sans questions, où l'on présume que la pensée scientifique est supérieure parce qu'elle produit une information quantifiable, généralisable, fiable et vraie.

Pour dépasser la modernité, nous devons continuer à nous opposer aux valeurs culturelles implicites et explicites qui structurent les pratiques d'évaluation 
prédominantes. Nous n'avons pas encore réussi à persuader les parties prenantes du besoin d'employer des interprétations herméneutiques qui tiennent compte de la complexité cognitive des actions menées par les étudiants afin d'évaluer leur compréhension profonde d'une matière ainsi que l'efficacité des programmes.

Une approche postmoderne nous permettrait de rétablir un point de vue plus réaliste sur les bienfaits de la pratique scientifique. Nous pourrions ainsi dépasser notre quête de certitudes, notre peur de la subjectivité et nos discours technologiques et développer une perspective plus saine sur les capacités et l'utilité de la science. De cette manière, nous serions mieux placés pour reconnaître que la vérité dépend souvent de son contexte historique et pour évaluer l'activité intellectuelle par rapport à la manière spécifique dont les étudiants utilisent et appliquent le savoir. Seule une reconnaissance de la complexité irréductible des processus d'apprentissage et d'écriture des étudiants peut créer un contexte propice à améliorer la pratique et la théorie de l'évaluation des étudiants.

\section{Mots clés}

théories sur l'évaluation d'ordre scolaire; évaluation de l'écriture au Canada; conséquences de la modernité; discours sur la technologie; responsabilité

"The discourse of assessment is now for the most part a discourse of technology" (Delandshire, 2003, p. 114).

Traditionally, education is considered a human science and as such, it works within modernist frameworks that dominate North American culture. Education uses a modernist discourse of technology that assumes an objective methodology is needed to produce certain results. ${ }^{1}$ Recent accountability initiatives in North America call for "increased demand for objective measures and assessment tools that provide evidence," and "hard data'2 that return the discipline to an era when the "psychometric properties of the assessments" (Crundwell, 2005, p. 2) appeared to be a major technological advance. Consequently, "large scale assessments [are] the vehicle of choice in the U.S. and Canada" (p. 1). While the desire for 'objective measures' of educational efficacy expresses a legitimate concern about institutional practices and learning outcomes, as Ginette Delandshire (2003) argues, our quantitative disposition places an "over-emphasis on methods of assessment" and on "standardized mandated forms of state assessment" (p. 114). While proponents of accountability call for objective measures, opponents have been able to substantially alter what Delandshire calls the education industry's 'business as usual' attitude.

The accountability movement presents quantitative assessments as a politically neutral 'technology.' In reality, its theory and methodology have an implicit, unarticulated theory: scientism. Most generally, scientism is a transparent, anterior disposition or belief that science - always and unquestionably — provides the correct solution to every problem. Anthony Giddens (1990) argues that scientism supports a "hidden curriculum" that teaches both the technical details of science and "general social attitudes, an aura 
of respect for technical knowledge. [...] Only if someone stays with science training for some time is she or he likely to be introduced to contentious issues or to become fully aware of the potential fallibility of all claims to knowledge in science" (p. 89). Modernity may have been 'weakened' by postmodernity, but educational assessments are, for the most part, mediated by this transparent "aura of respect."

North American culture is convalescing from some elements of modernity- but scientism is 'reemerging.' For Joseph A. Maxwell (1997), the reemergence is marked by political, cultural, and educational pressure for "accountability." It constitutes-not an absence of theory-but an implicit argument supported by "narrow and outdated assumptions about what it means to be scientific" (p. 36; also see Denzin et al., 2006; Lather, 2004; Lincoln \& Cannella, 2004). The antidote- postmodernity- as Steven Best and Douglas Kellner (1997) argue, is also emergent and "is strongly resisted by modernist orthodoxy [.... M]odern neo-positivist approaches still prevail in the social sciences" (p. 19), like education. While some argue that post-modernity has overcome the era of modernity, claiming a rupture from previous ways of thinking and acting, reports of the 'death of modernity' have been greatly exaggerated. Its tenets continue to order and constitute values - transmitted by cultural dispositions-and frame our conversations about assessment, technology, and educational methodology. ${ }^{4}$

Both modernity and post-modernity are polysemous conceptual frameworks. Therefore, I focus narrowly on the symptoms manifested in current educational and assessment practice and discourse. All too often, postmodern remedies are ineffective antidotes against the various manifestations of scientism. Those who argue that we should be pragmatic and accommodate scientism believe we should accommodate quantitative methodologies to ameliorate its symptoms. However, by accommodating modernism's procedural and methodological technologies, what Richard Rorty calls "being 'scientific," we displace and modify rather than transform and replace our dispositions and practices. Accommodation has not transformed, mitigated, or attenuated the causes that produce our cultural craving for quantitative, "objective" assessment.

As Rorty (1991) notes, rather than attempting to accommodate modernist discourses of technology and methodology, by "using weapons that [belong] to the tradition [we] are attacking [...t] these weapons should be thrown away" (p. 75). Many "weapons" of modernity manifest themselves as presuppositions about assessment practices: we expect certainty and objective knowledge; we assume methodology and calculative reasoning produce 'real' data; and, we marginalize direct assessments that are cognitively complex. To convalesce from modernity, we must continue to weaken the implicit and explicit cultural dispositions that transparently structure assessment practices. We have failed to persuade stakeholders we should assess cognitively complex performances that require hermeneutic interpretation to evaluate students' deep understandings and our programs' effectiveness. ${ }^{5}$ The discourse of technology is audible across many education institutions in North America. There are two consequences of this discourse: first, education is considered a quantifiable enterprise that serves our capitalist economy, and second, our assessment practices are based on a fear of subjective evaluations.

\section{Exordium: En-framing Education in the Discourse of Technology}


The discourse of technology values industrial and commercial conceptions of education, which commodify learning and distribution of knowledge, what Lincoln and Cannella (2004) call "academic capitalism" (see Fagan, 1995, pp. 65-6 \& 69-70; McEwen et al., 1995, pp. 100-102). If we trust only quantitative reasoning, we think, as Delandshire (2003) argues, "assessment is primarily understood as a technology" ( $p$. 113), while method appears to separate opinion from quantifiable facts. For Max Horkheimer and Theodor W. Adorno (1972), Enlightenment thinkers hope that "reason" will eliminate subjective values. Numbers become the schema to understand and structure reality and to create 'objective' knowledge. The "calculability of the world" dominates our relations to the environing worlds; anything not reducible "to numbers, and ultimately to the one, becomes illusion" (pp. 6-7).

We can see these consequences of modernity in a special issue of the Canadian Journal of Education designed to sample "current Canadian thought on accountability" (McEwen et al., 1995, p. 99). It has five anchor essays focusing on a particular province's approach to accountability, ${ }^{6}$ four responses by various stakeholders, and a rejoinder co-authored by the anchor essayists. The special issue demonstrates Delandshire's claim that "the absence of theoretical, conceptual, and philosophical debates with regard to assessment, may, however, result in practices that tend to reproduce themselves in a vacuum, resist change, and are disconnected from relevant issues of knowledge, power, and social organisations in general" (113). One of the respondents, W. T. Brownlee (1995), critiques the anchor essays because they are disconnected from teaching practices and rely on the specious claim that: "accountability initiatives are primarily concerned with measurement rather than evaluation. [...] The post-modernism view [...] is not evident here. [... T] permeated by a reductionist approach" (p. 80). ${ }^{7}$ The anchor essayists demonstrate only a marginally attenuated form of scientism - seen in traces of non-statistical practice. They gather some "qualitative information" on student, parent, and 'public' beliefs about educational efficacy (McEwen, 1995a, p. 9). On the one hand, opinion or attitude surveys of stakeholders drive the accountability agenda: subjective data, the beliefs or "perceived shortcomings" of a range of non-professionals are lumped together as "public dissatisfaction" (McEwen, 1995a, pp. 2-3). On the other hand, they hold teachers' assessments to be subjective - an "internal, invisible set of expectations" (McEwen et al., 1995, p. 104) - therefore, not trustworthy. Peterson and McClay (2010) report that Canadian teachers believe the "subjective nature of writing assessment" is "problematic." Teachers believe that "provincial standards exemplified $[\ldots]$ neutralized individual teachers' particular preferences" (p. 10) because the standards create "reliability" in large-scale assessments (p. 11).

The discourse of technical "quantification" runs through four of the five anchor essays. Only Lorna M. Earl (1995 \& 1999) warns of dangers of using and interpreting quantitative data (p. 54); the other essays enframe education in the quantitative discourse of business: taxpayers "want and have a right to know if they are getting value for their investment" (McEwen, 1995b, p. 28). They present education as a profit making "enterprise," (McEwen, 1995b, p. 29), "society is a major client" of education, and "the product is the quality of student learning" (McEwen et al., 1995, p. 100). They combine the discourse of business with a belief in methodological procedures: "policies are expected to assist in improving the quality of education. Each policy is accompanied 
by definitions, legislation, and regulations and procedures" (McEwen, 1995b, p. 30). Respondent Allan Bacon (1995) aptly objects to their application of modern business discourse and practices to education. He challenges their assumption that education is a commodity exchange in which parents "invest" in a stock (school) that produces education (i.e. employability skills) "consistent with workplace requirements" (McEwen, 1995b, p. 30). He denies that calculative reasoning can manage and order education. Bacon argues that "better management" does insure success: "Education is not a business. Concepts such as 'quality control' are inappropriate. It implies that children are mass-produced like widgets or cookies, as if they are all the same" (p. 89). Because they consider learning to be a product, they use productionist methodologies to get "hard information" and require an "empirical base of information" (Fagan, 1995, p. 65).

North Americans apply modern industrial methods and create a covert theory of education. Michael Williamson (2009) identifies three competing models of education, two of which are the factory management model and the bureaucratic management model (pp. 59 ff). Both models "share an underlying commonality which leads to a drive for more efficient education"; they share "the basic premise that efficiency maximizes profits" (p. 62). For Fred M. Hechinger (2003), "the factory model" of education reproduces four key values - punctuality, regularity, attention, and silence -in working class students (pp. $4 \mathrm{ff}$ ). Both models produce a "hidden curriculum of work" that structures our schools. It is a pedagogy based on mechanical rote learning, highly controlled behavior, a fragmented curriculum, little choice in content or process, few opportunities to be creative, and very little emphasis on higher order thinking skills (Anyon, 1980, pp. 73-7). Education serves business in both models; both use policies established in the industrial revolution to define the purposes of education; finally, both reduce knowledge to an object.

Charles Dickens (1967) describes another consequence of the factory model of education: a pedagogy that objectifies knowledge and uses mercantile instrumentalism reproduces its own values. ${ }^{8}$ Mr. Gradgrind hopes to 'reform' the English educational system by making reason its foundation, by applying scientific principles used to manufacture goods: "Now, what I want is, Facts. Teach these boys and girls nothing but Facts. Facts alone are wanted in life. Plant nothing else, and root out everything else. You can only form the minds of reasoning animals upon Facts" (p. 47).$^{9}$ These models of education create what John Dewey (1966) calls "dissipating" curriculums (p. 139) embedded in the mystifying discourse of technology. Public understanding of the role of education in North America remains within the frameworks of a factory/business model that are designed to aid commercial growth, provide students with useful information and skills for the 'real' world.

These two models reduce learning to what Paulo Freire calls a banking exchange: educators deposit objective knowledge in passive students' brains. Both models misconstrue the inherent complexity of educative tasks like contextual analysis, working with sequences of text-based tasks, synthesizing various and disparate concepts, applying concepts with understanding, and performing and appropriating knowledge and exhibiting deep understanding. Scientism believes that knowledge is an object, which is mechanically reproduced inside the docile heads of students. It must be so if it is to be reduced to a mechanical "right or wrong answer- to a clerical decision" (Williamson, 2009, p. 66). Modern technology reduces assessment to clerical decisions, 
increases "effectiveness and efficiency" (Fagan, 1995, p. 65; McEwen, 1995a, p. 2; McEwan, 1995b, p. 28; McEwen et al., 1995, p. 100), reduces complex social interactions to "input variables," and produces an "optimal return" on public investments (Fagan, 1995, p. 69). North Americans continue to demand curriculums that place too much value on practical skills rather that higher order habits of mind-capabilities to critically analyze knowledge.

Another respondent, Philip Nagy (1995) argues that most of the anchor essays assume an ahistorical capitalist ideology that must be re-contextualized within a history of North American industrialization. He aptly notes that North Americans' "dissatisfaction with public education" arises from "parents' fears that public schools are failing" (McEwen et al., 1995, p. 106). Accountability is driven by the "public's fear" (p. 106); Nagy aptly shows how fear creates "widespread historical myopia, a mistaken belief that schools used to be a lot better" (p. 93). While the accountability movement distrusts subjective evaluations, at the same time, they promote an equally subjective and mostly mistaken belief that public schools are declining. Since moving into global and high technologies, the demands of the market have raised the educational bar much higher than in the previous industrial era. What is driving the fear is the reality that it is harder and harder for under-educated people to find the kinds of unskilled labor that existed previously, during the low technology era of modernism.

\section{Contextualizing the Quest for Certainty as a Modernist Attunement to Calculative Reasoning and Science}

Galileo was especially influenced by his conviction that Nature is essentially mathematical. [... H] is ideal was [to develop] a scientific view of the world in terms of mathematical formulae. [... H]e tried to express the foundations of physics and the observed regularities of Nature in terms of mathematical propositions. [... He concludes] that mathematics is the key to the actual structure of reality. (Copleston, 1963a, pp. 92-8)

While Galileo is generally thought of as a scientist, the early modern scientists thought of themselves as philosophers who inquire into "the actual structure of reality." As Copleston (1963b) states, mathematics is the model of reasoning that provides both empiricists and the rationalists with clarity, certainty, and an ideal methodology to inquire into 'actual reality' (pp. 28-36). According to John Dewey (1960), this $17^{\text {th }}$ century belief is related to the fear of subjectivity and to the mutability of knowledge. Mathematical knowledge is "couched in mechanistic terms" and fixed (p. 2). For Rorty (1995), scientism is "the doctrine that natural science is privileged above all other areas of culture, that something about natural science puts it in closer touch with reality than any other human activity" (p. 4). Scientism has both cultural and epistemological implications: it searches "for some final vocabulary, which can somehow be known in advance to be the common core, the truth of, all the other vocabularies which might be advanced in its place" (Rorty, 1982, xlii). Modernism extends the purview of natural science to all of existence; then, all phenomena, human and non-human, are treated as if they can be reduced to objective information, to certain and strong representations of reality. Modernists believe calculative reasoning is the way to assess 'actual' students' learning. ${ }^{10}$ 
In the rationalist tradition of philosophy, Spinoza purports to develop an ethical system using a "geometrical" method; Leibniz purports to develop "a universal calculus that allows all decisions to be calculated by an algorithmic procedure" (Hollinger, 1984, 15). Descartes claims we can replace subjective experience with geometry and mathematics - scientific technologies to render truth and certainty exclusively in apodictic, or demonstrative discourse. Ernesto Grassi (2001) notes, both Locke and Kant fear subjectivity and argue that philosophy should only make demonstrative assertions that are objectively certain; rhetoric makes subjective and emotional claims, rife with "pathetic influences - the influences of feeling - [that] disturb the clarity of rational thought" (p. 18; also see Grassi, 1983, pp. 16-7). ${ }^{11}$ There are various forms of calculative reasoning in the modernist epoch; most often, they characterize humanistic knowledge claims as rhetoric, as probable truths, which are, at best, 'weak,' and, at worst, considered doxa, or merely opinion. The desire for certain, objective, and universal truth leads to a complete rejection of subjective and emotional knowledge; ironically, the quest for certainty is an emotional realization that we have not succeeded in producing valid and reliable knowledge, especially about cultural products, like writing, even though we have done much to transform human beings into objects to be studied and measured.

\section{"Certainty Evades Us"}

Friedrich Nietzsche (2001) identifies this type of "desire for certainty" as a nonrational "inmost craving and deepest need" that characterizes modernity (author's emphasis; p. 30): the "impetuous demand for certainty that today discharges itself in scientific-positivistic form among great masses" (author's emphasis; p. 205). The "demand for certainty" is an anterior and transparent cultural disposition that frames and constitutes the public and commonplace prejudice that assumes science is the source of all worthwhile knowledge (p. 205). Dewey (1933) agrees with Nietzsche, arguing that the quest for certainty is an emotional symptom of a cultural disposition; we persuade ourselves that we must be "devoted to intellectual certainty for its own sake. Actually, [we] want it because of its bearing on safeguarding what [we] desire and esteem- [...] warranting the validity of intellectual beliefs [and] certification [...] of the antecedent immutable reality of truth" (pp. 10-11). ${ }^{12}$

Ironically, the quest for immutable knowledge discloses an emotional desire that drives philosophy from ancient Greece to modernity. The specious claim that there are two distinct and unequal realms of knowledge frames our emotional desire to overcome uncertainty and change; one is the realm of pure reason (unbiased by subjectivity or emotion) that uncovers universal and stable knowledge; the other a realm of practical actions that disclose contingent or probable knowledge. The emotional drive to escape from uncertainty is clearly visible in Descartes' rejection of probable rhetorical truth and his claim that rationalist philosophy produces "perfectly known" truths. Descartes (1961) argues that we must reject knowledge that is based upon verisimilitude - the rhetorical standard of truth:

All science is certain, evident knowledge ... [T] herefore, it is better never to study than to turn our attention to such difficult topics that, being unable to distinguish the true from the false, we are forced to accept doubtful conclusions as certain [... I]n accordance with this rule, we reject all knowledge that is merely probable, and judge that only those things 
should be believed which are perfectly known, and about which we can have no doubts. (emphasis added; p. 5)

Descartes' Rules provides three central assumptions that remain operative in educational and writing assessment methodology: 1) inquiry that does not result in evident knowledge has no value, 2) to "know more certainly" means we must reject merely probable rhetorical truths, and 3 ) research must reduce ontological complexity to simple data points (p. 42).

Gianni Vattimo (1991) argues that post-modernity starts with Nietzsche's analysis of the concomitance of truth and errancy (pp. 164ff). Modernity assumes that calculative reasoning and proper methods can, in the end, overcome errancy. As Peter Elbow (1986) notes, "Certainty evades us" (p. 254). The modern craving for objectivity and certainty is a cultural disposition that structures traditional assessment. Descartes' claim that certainty is the goal of scientific method continues to hold North America in the epoch of modernity: "the era stretching from the late Renaissance to sometime early in the twentieth century can be characterized as an era in which we not only accepted Descartes' goal of certainty as attainable, but we came to assume certainty as a necessary feature of knowledge: if it's not certain, it's not knowledge" (emphasis added; Elbow, 1986, p. 257). Descartes begins the modern quest for methodologies to reduce complex knowledge to simple, certain propositions, which unfortunately produce a desiccated concept of knowledge and truth. ${ }^{13}$

Elbow (1994) wants to convince others that while quantitative methods are supposed to provide "data" that are certain, they do not. He believes assessment professionals can cure this quantitative disposition through "sound practice" and rhetorical persuasion (p. 48). The assumption that writing assessment must follow scientific methodologies leads to a vicious circle: on the one hand, doubting quantitative methods; and, on the other hand, believing we must use quantitative methods because they produce objective results. Roberta Camp (2009) notes that some practices- like holistic grading or portfolio assessment- developed by compositionists have lead to "a compromise accommodating both traditional psychometric expectations for reliability and the concern for validity expressed by teachers of writing and others convinced that judgments about writing ability should be based on writing performance" (p. 103). According to Camp, psychometricians and compositionists share a post-empiricist world-view, but are having an inter-paradigm conflict. One side promotes reliability, and the other, validity. While these kinds of compromises attenuate some problems with quantitative assessments, they do not challenge the intellectual framework that legitimates the nearly exclusive use of calculative methodologies. William Condon (2001) argues quantitative methods cannot be applied to complex performances, particularly of academic writing (p. 32-3; also see Lynne, 2003, pp. 37-43). ${ }^{14}$ Even if Camp is correct that accommodation ameliorates particular problems with the quantitative paradigm, it continues to exclude humanistic alternatives from educational assessment because Descartes' heirs continue to frame its methodology.

\section{Assessment Literacy: Bamboozled by Methodology}

Descartes (1961) states that the efficacy of scientific methodology depends upon "the order and arrangement of those things upon which the power of the mind is to be concentrated in order to discover some truth. And we follow this method exactly if we 
reduce complex and obscure propositions step by step to simpler ones and then advance by [...] the intuitive understanding of the very simplest to the knowledge of all the rest" (p. 19). Initially, Descartes suggests that science orders and arranges evidence. However, Descartes' method goes further than arrangement because it also reduces complexity. ${ }^{15}$ Complex evidence always produces pluralist, probable, and 'weak' claims, which if related to facts about the world, empiricists find acceptable (Copleston 1963b, p. 37). Descartes intends to eliminate probable and 'subjective' meanings by reducing complex evidence to simpler data. After complexity is reduced to simple data, one may advance 'certain' propositions. Methodology simplifies data so that it can be stated in propositions, which are either 'valid' knowledge (correct) or errant knowledge (incorrect).

Descartes' view of method is a cultural meme that reproduces itself in various iterations across the epoch of modernism: "The main theme of 'Continental' philosophy in our century has been criticism of the presupposition [...] that what matters is being 'scientific' in the sense of rigorously carrying through some procedure (dialectical, inductive, hypothetico-deductive, analytical, or whatever)" (Rorty, 1991, p. 75). In the epoch of modernity, the concept of 'being scientific' and its attendant discourse of technology is hegemonic not just in regard to method: "since the period of Descartes and Hobbes, the assumption that scientific discourse was normal discourse and that all other discourse needed to be modeled up on it" (Rorty, 1979, p. 387) dominates notions of truth and certainty. Scientific methodology reinforces a disdain for contingent concepts of truth and hermeneutic uncertainty.

Modernity effectively denigrates the value of rhetorical truth and promotes the belief that only scientific methodology produces 'real' knowledge. Hans Georg Gadamer's (1990) Truth and Method is an extended critique of this modernist belief. For Gadamer, rhetorical and practical reasoning use pathos and ethos to disclose truths, in a probable yet adequate way that is rooted in contextual, historical, and humanist traditions. Vattimo (1997) notes that Gadamer's argument counters the primacy of scientific methods and the notion that objective, certain results, are truth: "Gadamer's Truth and Method [...] explicitly takes as its point of departure the problem of truth of those forms of knowledge, like the human sciences, that are not reducible to positivescientific method, and ends by constructing a general theory of interpretation" (p. 4). Gadamer, like Heidegger, describes understanding and interpretation as modes of learning that are both formative and performative.

Gadamer urges us to retrieve, as Giambattista Vico (1990) does in On the Study of Methods of Our Time, important humanist educational principles and rhetorical approaches to knowledge. Natural science methodologies, Gadamer argues, impoverish humanist traditions by subsuming rhetoric, in which truth is never certain and fixed, to scientific methodology, which desires certain and disinterested knowledge. Our desire for efficient, objective methods, which filter subjectivity out of 'data,' and reduce the data to quantifiable numbers, is the most common rationale for large-scale assessments in North America. Doing so, Gadamer (1990) argues, we apply inappropriate and foreign 'methods,' designed to reduce and simplify non-human objects, to complex cultural performances. ${ }^{16}$

We [...] must laboriously make our way back into this [humanist] tradition by first showing the difficulties that result from the application of the 
modern concept of method to the human sciences. Let us therefore consider how this tradition became so impoverished and how the human sciences' claim to know something true came to be measured by a standard foreign to it-namely the methodical thinking of modern science. (emphasis added; p. 24)

Vico's defense of rhetoric is a counter-argument against Descartes' claim ${ }^{17}$ that method purifies thinking from error. For Vico (1990), Descartes' methodology 'harms' pedagogy and demeans 'common sense,' which relies on probable judgments:

The main purpose [of Descartes' method] is to cleanse its fundamental truths not only of all falsity, but also of the mere suspicion of error[. He] places upon the same plane of falsity not only false thinking, but also those secondary verities and ideas which are based on probability alone, and commands us to clear our minds of them. Such an approach is distinctly harmful, since training in common sense is essential [.... C]ommon sense arises from perceptions based on verisimilitude [... and,] besides being the criterion of practical judgment, is also the guiding standard of eloquence. (p. 13) Gadamer (1990) agrees with Vico; Descartes' methodology eliminates history, affect, and human experiences (common-sense); it renders students "unfit" to understand rhetorical truths and common sense: "the eikos, the verisimilar, the 'probable' [... and], the 'evident,' belong in a series of things that defend their rightness against the truth and the certainty of what is proved and known" (p. 485). ${ }^{18}$ Vico goes "far beyond the defense of rhetorical persuasion" because he shows there is a kind of knowing that "lies outside the rational concept of knowledge" (p. 21). Rhetoric has a practical value: it 'jolts' a student or an audience with affective appeals, thereby creating new dispositions, new knowledge (p. 15).

Jurgen Habermas (1971) argues that scientism is an epistemological assumption: "knowledge is defined by what the sciences do and can thus be adequately explicated through the methodological analysis of scientific procedures." Focusing mostly on procedures, scientism eliminates self-reflection and "does not coincide with science" (p. 67; also see Maxwell, 2004, p. 36). ${ }^{19}$ Scientism distorts the technicity of the sciences because it focuses on "methodological inquiry into the rules for the construction and corroboration of scientific theories" (p. 67). Another relevant consequence to educational assessment occurs because inquiry is "flattened out into methodology" therefore "it loses sight of the constitution of the objects." Quantitative methods conceal "the problems of world constitution" (p. 68); the consequence of this is that we lose sight the way that knowledge is a historical and dialogic event. Despite the hegemony of methodology, Bob Broad (2003) claims, "the field of writing assessment has no adequate method" for evaluating writing: "contemporary writing assessment stands in urgent need of a rigorous method for" assessing writing (p. 119). Therefore, he develops new "a workable method (supported by a well developed theory) by which instructors and administrators in writing programs can discover, negotiate, and publicize the rhetorical values they employ" while assessing writing (p. 5).

- Reliability, Validity, and Constructionist Epistemology

Recently Broad's (2003) What We Really Value, and two other scholars-Brian Huot (2002), in (Re) Articulating Writing Assessment and Patricia Lynne (2004), in 
Coming to Terms, all argue that social constructionist epistemologies, which use rhetorical criteria, would legitimate context-based writing assessments. While Broad's method, Dynamic Criteria Mapping (DCM), and Huot's contextual theory challenge quantitative methods, both approaches try to overcome, transform, or "reinscribe" (Lather, 1993, p. 674) key terms - validity and methodology — used by quantitative research. Only Lynne advocates that composition and education scholars follow Rorty's advice: to look for a new vocabulary and conceptual framework for assessment rather than revising modernist methodology, particularly the concepts of reliability and validity. Lynne aptly notes, "Without an alternative vocabulary with which to talk about assessment, objectivist thinking will continue to direct the ways arguments about largescale assessments are conducted" (p. 43). For Lynne, "compositionists' understanding of large scale assessment" continues to be framed by modernist assumptions about 'reliability' and 'validity,' which constitutes its scientificity; using these concepts "scholars turn over judgments about the value of writing assessment to those outside composition" (p. 67). We accept the foreign authority educational measurement theory by "actively proclaiming the limitations of educational measurement theory for at least two decades yet [we] continue to employ the principles of validity and reliability as justifications for large-scale assessment practices" (p. 163). This tendency shows our acceptance of "the authority of educational measurement theory to explain, define, and justify writing assessment" (p. 164), even as we try to develop assessments based on rhetorical and hermeneutic principles.

\section{Reliability:}

All three books argue that qualitative assessments should not focus on 'reliability' (Broad, 1994, 2003, p. 7; Huot, 2002, pp. 33ff; Lynne, 2004, pp. 37ff; also see Moss et al., 1992; Moss et al., 1994) because it depends on a consensus view of correctness. Reliability is the assumption that graders must closely agree if the evaluation is fair. Elbow (1986) notes, "in the name of 'fairness' and 'science' [... we] seek ever higher levels of numerical agreement" (p. 264). Broad $(2003,1994)$ aptly critiques the way that traditional writing assessment strives to eliminate disagreement between raters so that an absence of inter-rater reliability is thought to mean a deflective or unfair evaluation. This belief follows modernist dogma that privileges consensus or agreement as the primary demonstration of a reliable evaluation (p. 7). Like Pamela Moss, Broad and Huot recognize that assessment is a subjective activity and they reject the calculative technology that produces reliability by sweeping away all interpretative disagreements. ${ }^{20}$ If we reject the principle of reliability, two principles emerge that weaken quantitative writing assessments: all writing assessments are interpretative evaluations not objective measures of ability; therefore, we should not expect a strong consensus because assessment is essentially a hermeneutic practice.

\section{Validity:}

Huot (2002), like Broad, argues that compositionists should follow the lead of Moss to rehabilitate the concept of validity in terms of post-empirical theory and empirical evidence "rather than as a technical apparatus" (p. 57). The implicit assumption of those who use validity as a weapon against reliability is clearly stated by Maxwell: a "concern for validity [is] the essential characteristic of science" (p. 37). Both 
Huot and Broad call for compositionists to revise validity by focusing on "its rhetorical sense" (Huot, 2002, p. 56; Broad, 2003, p. 5). Broad and Huot "reconceptualize validity [so] that [it] is grounded in theorizing our practice" (Huot, 2002, pp. 52ff; Broad, 2003, pp. 9 ff; also see Lather, 1993, p. 674; Maxwell, 2004, pp. 36-7). They argue we can and should rehabilitate the concept of validity if we apply it methodically to qualitative empirical evidence. Implicitly, this position supports the modernist claims that humanistic or qualitative inquiry produces evidence that is weak - unsupported assertions, opinions, or lore, rather than 'reasonably certain,' objective, and empirical evidence. $^{21}$

\section{Social Constructivist Epistemology:}

All three authors use a social constructionist epistemology to justify their assessment methodologies (Broad, 2003, p. 119; Huot, 1996, p. 161; Lynne, 2004, 119 ff). For Broad and Huot, new interpretations of validity "in measurement theory are [...] supported by" theories about "the social construction of knowledge." They claim we can re-inscribe epistemology so that it is consonant with "a postmodern age" (Huot, 1996, p. 161). Consequently, they define validity as a social and local form of empirical evidence provided by indiginous definitions of good writing. ${ }^{22}$ All three authors refer to Egon G. Guba and Yvonne S. Lincoln's, Fourth Generation Evaluation, a constructivist manifesto of post-empirical epistemology. Denzin and Lincoln (2003) note that "[h]istorically qualitative research was defined within the positivist paradigm, where qualitative researchers attempted to do good positivist research with less rigorous methods and procedures" (p. 14). More recently, Lincoln repudiates the idea that we must accommodate scientism arguing that constructivists misdiagnosed the strength of modernist disposition of certainty and objective truth: "We [Constructivists] have deluded ourselves that the discourse of constructivism could resemble the discourse of other science, and I and others were wrong. [...] The discourse of constructivist inquiry must be recontextualized in such a way as to make it apparent that science and knowledge are not transcendent but, instead, another set of 'heuristic fictions' for meaning-making in our world" (p. 86). The proponents of constructivism delude themselves by thinking that constructivist epistemology will be accepted by proponents of quantitative methods.

Broad's DCM theory overdramatizes the value of locally produced knowledge by creating an elaborate method to identify a plethora of local communities' values; then, following Descartes' model, they collect and reduce them to a small set of "dynamic criteria." His work, like that of Huot, rejects reliability as a methodological concern but attempts to accommodate modernity's method fetish by accepting the premise that methodology must be grounded in epistemology and must produce an, albeit attenuated, social definition of validity.

\section{- The Question of Exclusionary Practices}

The scientists of the mid-twentieth century [...] have entered the period of postmodern science. For natural scientists today, the classical posture of pure spectator is no longer available even on the level of pure theory; and objectivity of scientific knowledge can no longer rely on the passivity of the scientists' objects of knowledge alone. In the physical sciences, objectivity 
can now be achieved only in the way it is in the human sciences: the scientist must acknowledge and discount his own reactions to and influence on that which he seeks to understand. (Toulmin, 1982, p.97)

Stephen Toulmin (1982) claims postmodern science has overcome the "classical" dispositions of modern science. While modern science and the discourse of technology successfully control, dominate, and commodify nature, as Toulmin notes, they also fail us in two ways. First, the fear of subjectivity, the quest for certainty, the desire for objectivity, and the commodification of the environment continue to dominate cultural dispositions; consequently, many proponents of modernism continue to dispute any other ways of understanding the world (Horkheimer \& Adorno, 1972, pp. 3-42). ${ }^{23}$ Toulmin (1982) thinks that postmodern science is no longer concerned with objectivity and certainty; either produces "an unsuitable method and an irrelevant ideal" (p. 96). Toulmin (1982) argues that postmodern scientists believe that the epoch of "modern science" is over and that hermeneutics is more important than methodology (p. 95). However, he misdiagnoses the virulence of our cultural dispositions, as demonstrated by exclusionary practices enacted to resist change. ${ }^{24}$

Scientism is reemerging, for example, in a report by the American National Research Council that undercuts Toulmin's claim: the NRC "rejects the postmodernist school of thought when it posits that social science research can never generate objective or trustworthy knowledge" (cited in Lincoln \& Cannella, 2004, p. 10). The NRC report, Lather (2004) argues, is an "exclusionary force," "striking in its disavowal of different views of evidence, analysis, and purposes" (p. 19). It rejects postmodern notions of complexity and uncertainty; and, it promotes modernist instruments to assessment, methods to produce scores, and practices to interpret scores in "a specialised and technical knowledge" (Delandshire, 2003, p. 115). Exclusionary practices are not solely a local concern: "Around the world, governments are attempting to regulate scientific inquiry by defining what counts as 'good' science" (Denzin et al., 2006, p. 769). Denzin et al. (2006) note that proponents of quantitative research use political power to suppress alternative assessment practices. Exclusionary and regressive, "re-emergent scientism" uses a "methodological fundamentalism" to regulate "philosophical, epistemological, political and pedagogical issues" (p. 769) in education: "Conservative regimes are enforcing evidence- or scientifically based, biomedical models of research" (p. 770). As Melissa Freeman et al. (2007) argue, governments that "legislate scientific practice and mandate research design threaten to harden the boundaries of what counts as science, to devalue many qualitative research endeavors, and to limit creative research practice of all kinds" (p. 25; also see Denzin et al., 2003, pp. 769ff ; Earl, 1999, pp. 4-6; Lather, 2006, pp. 783-84). ${ }^{25}$

The discourse of technology is exclusionary in two ways. Humanists working in assessment internalized scientism; we can see the residue of scientism in Elbow and Belanoff's (1997) reflection on their work as assessment specialists. The exigency of their essay is to analyze their path-breaking use of portfolios as an alternative form of writing assessment; yet, they claim, "we are not assessment specialists" (p. 21). Even though they are ambivalent about the efficacy of quantitative assessments, they depreciate, and perhaps distrust, their professional status in the disciple:

[W]e have not mastered the technical dimensions of psychometrics. That does not mean we don't respect the field; we agree with Ed White that one 
of the greatest needs is for practitioners and theorists like us to talk to psychometricians. But we don't feel comfortable doing that so long as they continue to worship numbers as the bottom line. [...] The most important lesson we've learned is that people can do useful work in assessment without being on top of technical psychometrics. (emphasis added; p. 21) On the one hand, the primary quality of "assessment specialists" is technical fluency in psychometrics. Elbow and Belanoff agree with Edward M. White (1994), who argues that if compositionists want stakeholders to consider what we do as "genuine assessment," we must produce evidence that is "beyond assertions and lore" (author's emphasis; p. 29) ${ }^{26}$ On the other hand, they demonstrate that "useful work" in writing assessment can occur without psychometrics. Additionally, Elbow and Belanoff (1997) understand both that assessment is interpretive and human performances complex: "no complex performance can be accurately summed up in a single number because it almost always has stronger and weaker aspects or dimensions" (p. 28). Their ambivalence about psychometric methods is acerbated by the reality that pragmatic efforts to alter psychometric methods have had little impact on assessment technologies; therefore, they withdraw support for a "conversation."

Second, those who call for 'rigorous,' empirical assessments, as in the NRC, apply "political pressure" and publicly critique alternative approaches. According to Ruccio and Amariglio (2003), public critiques are used to demean and silence humanists by claiming their methods do not produce "real" evidence. But, quantitative assessments don't produce "real" evidence either. Some, like Lorna M. Earl (1999 \& 1995) warn us that statistics are deceptively simplistic and often result in "misuse and misinterpretation" (p. 47 \& p. 54). Statistics "give the illusion of accuracy and objectivity, but the numbers" must be interpreted and contextualized in terms of the how the test defines "performance" (1999, p. 47). Others, like Chris M. Anson (2008), claim that quantitative methods produce empirical evidence that moves us "beyond a culture of" argument. Anson claims we should use post-empiricist methodology to produce empirical evidence with "some level of certainty" to end the argument over evidence ( $p$. 12; also see Broad, 2002, p. 3; Huot, 2002, p. 178) ${ }^{27}$ If we examine the exigency of his essay - his university's writing program was publicly critiqued- his conclusions about empirical evidence are not justified: "There is nothing meritorious enough about the report, in scholarly grounding or investigative sophistication, to deserve national attention" (emphasis added; p. 11). He claims empirical research is the only way to refute unmeritorious claims about composition practices; ironically, he presents a convincing argument that the report has no merit without empirical evidence.

Anson's argument implicitly supports the modernist fear of subjectivity: that argumentation merely expresses beliefs: "if we continue to rely on belief in our pedagogies and administrative decisions, whether theorized or not, whether argued from logic or anecdote, experience or conviction, we do no better to support a case for those decisions than what most detractors do to support cases against them" (author's emphasis; pp. 11-2). His argument cedes the regulatory power of program and educational assessment to methodological fundamentalism: "Conservative regimes are enforcing evidence- or scientifically based, biomedical models of research (SBR). [...] So-called evidence-based research [... fails] to recognize that the very act of labeling some research as 'evidence-based' implies that some research fails to mount 
evidence - a strongly political and decidedly non-objective stance" (Denzin et al., 2006, p. 770). Post-empirical epistemology impedes our convalescence from modernity because it fuels a vicious dynamic - one camp of stakeholders asserts that we should apply 'rigorous' methods to educational assessments - while the other seeks to accommodate and attenuate an outdated concept of scientific 'rigor.'

\section{- Assess Students' Understanding by Demonstrations of Complex Performances}

Healthy doses of rhetoric and hermeneutics can counterbalance the modernist dispositions that frame educational assessment. They disclose the performative character of learning, writing, reading and thinking. They can help us to focus students' proficiency in understanding and interpreting essential questions and problems, rather than focusing on methodology or epistemology. Without methodology or epistemology, we can frame assessment practices to disclose the ontological complexity of our task. A postmodern disposition would implement rhetorical criteria for assessments so that we articulate contingent results, would design assessments with cognitive complexity, and would assess performances that demonstrate students' ability to apply their understanding for their own uses and purposes.

\section{Rhetoric Values the Probable}

Even if one accepts the possibility of a 'weak' epistemology- i.e. one that produces relatively certain information - there are serious doubts about whether or not epistemology can or should be applied to cultural objects. We should return to rhetorical traditions because, as Gadamer (1990) notes, only rhetoric asserts "itself against modern scientific methodology" (p. 485). Rhetoric and hermeneutics, which appeal to practical reasoning, are both a sufficient way to adjudicate truth claims and articulate a sustained and persuasive critique of traditional assessment practices. Rhetoric and hermeneutics obviate the quest for certainty that motivates modern methodologies and epistemologies. Both will help us to shift the focus of accountability proponents to the best available evidence to support the most probable interpretation, rather than "correctness." There is no methodology, no epistemology that can untangle the ontological event structure and sift truth from errancy in a consistent, reliable, and universal manner. Rather than imagining student learning is worldless and objective, rhetoric engages us in legitimatizing interpretative claims to stakeholders.

\section{Assessing Cognitively Complex Performances}

Robert L. Linn et al. (1991) note, we can develop performance tasks "that are valued in their own right" (p. 15). The same types of complex cognition that students face in the classroom can be used for assessment. Too often in assessment scholarship, "performance" simply means 'performance' doing something - like a standardized test. Insisting on an appropriate definition is quite important because, if properly constructed, performance assessments confound Descartes' methodological heirs in the educational testing industry. If assessment tasks and criteria are complex, performances cannot be standardized or simplistically reduced to numbers. We should 
take advantage of the complexity of writing to "open up space to explore" more meaningful assessments (Condon, 2001, p. 32).

Authentic performances confound the modernist model because they cannot be reduced to reliable, valid, and generalizable propositions. We can develop new interpretations of assessment, such as Theodore R. Sizer's (1992) concept of "exhibitions." Truly performative educational assessments don't ask students to display knowledge; rather, they ask students to engage in essential problems and to use knowledge by applying it (pp. 84-5). If we assess complex performances, we disclose how students understand, apply, and appropriate intellectual concepts for their own purposes. Debates can be contextualized in sequences of readings about substantive problems or issues. Assessment tasks that are constructed around public and professional problems, which cause and require debate, are interpretative performances that constitute rigorous educational outcomes.

\section{Assess for Student Understanding, not Methodological Efficiency}

As Linn et al. (1991) argue, "performance-based assessments [...] place greater emphasis on problem-solving, comprehension, critical thinking, reasoning, and metacognitive processes" (p. 19). They require higher order thinking skills such as application, analysis, and synthesis to demonstrate understanding of a deep and narrow problem. In this way, we assess "a student's disposition to use knowledge effectively when faced with important new situations" (Sizer, 1992, p. 111). Writing and education are cultural products with ontological complexity that constitute and disclose human world-hood; disclosure of world-hood occurs in active understanding. When faced with the complexity and uncertainty of authentic open-ended writing assignments, contextualized in text-based learning, quantitative methods fail to assess the depth and texture of students' knowledge.

Some, like McEwen (1995b), argue that assessment checks for educational efficiency: "The goals, or intended benefits, of implementing indicator systems are to assess the effectiveness and efficiency of the educational enterprise" (p. 28). But, efficiency, in the service of profit or cost saving, is not an educational goal. Rather than systematically and simplistically reducing the complexity of teaching and learning, we need to admit the messy and unruly interanimation of students, engaging in challenging tasks, teachers, creating sequences of assignments around essential issues that engage disciplinary problems, and institutions, realizing educational assessment must focus on performances of deep understanding. In this way, we evaluate student, teacher, and institutional proficiencies realistically and substantially.

A postmodern disposition allows us to recover a balanced view of the benefits that scientific practices give us. We can convalesce from the quest for certainty, the fear of subjectivity, and the discourse of technology, and develop a healthier disposition regarding both the power and usefulness of science. Such a recovery would create new dispositions to accept probable truths as events within historical horizons and to assess intellectual activity - how students use and apply knowledge. Only a retrieval of the irreducible complexity of student learning and writing will create the context to revise the practice and theory of educational assessment. 


\section{References}

Anson, C. M. (2008). The intelligent design of writing programs: Reliance on belief or a future of evidence. WPA: The Journal of the Council of Writing Program Administrators, 32(1), 11-36.

Anyon, J. (1980). Social class and the hidden curriculum of work. Journal of Education, 162(2), 67-92.

Arendt, H. (1978). The life of the mind. New York, NY: Harcourt. 
Bacon, A. (1995). The teachers' perspective on accountability. Canadian Journal of Education, 20(1), 85-91.

Best, S., \& Kellner D. (1997). The postmodern turn. New York, NY: Guilford.

Broad, R L. (1994). "Portfolio scoring": A contraction in terms. In L. Black, D. A. Daiker, J. Sommers, \& G. Stygall (Eds.), New directions in portfolio assessment (pp. 263-76). Portsmouth, NH: Heinemann.

Broad, B. (2003). What we really value: Beyond rubrics in teaching and assessing writing. Logan, UT: Utah UP.

Brownlee, W. T. (1995). Accountability initiatives: Necessary or contrived? Canadian Journal of Education, 20(1), 80-84.

Camp, R. (2009). Changing the model for the direct assessment of writing. In B. Huot and P. O'Neill (Eds.), Assessing writing: A critical sourcebook (pp. 102-30). Boston, MA: Bedford/St. Martins.

Condon, W. (2001). Accommodating complexity: WAC program evaluation in the age of accountability. In S. H. McLeod, E. Miraglia, M. Soven and C. Thaiss (Eds.), WAC for the new millennium: Strategies for continuing writing-across-thecurriculum programs (pp. 28-51). Urbana, IL: NCTE.

Copleston, F. (1963a). A history of philosophy: Late mediaeval and renaissance philosophy. Vol. 3 Part 2. New York, NY: Doubleday,

Copleston, F. (1963b). A history of philosophy: Modern philosophy: Descartes to Leibniz. Vol. 4. New York, NY: Doubleday.

Crundwell, R. M. (2005 May 24). Alternative strategies for large scale student assessment in Canada: Is value added assessment one possible answer. Canadian Journal of Educational Administration and Policy, 41, 1-10.

Delandshire, G. (2003). Implicit theories, unexamined assumptions and the status quo of educational assessment. Assessment in Education, 8(2), 113-33.

Denzin, N. K., \& Lincoln, Y. S. (2003). Introduction: The discipline and practice of qualitative research. In N. K. Denzin \& Y. S. Lincoln (Eds.), Strategies of qualitative inquiry (pp. 1-45). ( $2^{\text {nd }}$ ed.) Thousand Oaks, CA: Sage.

Denzin, N. K., Lincoln, Y. S., \& Giardina, M.D. (2006): Disciplining qualitative research. International Journal of Qualitative Studies in Education, 19(6), 769-82.

Descartes, R. (1961). Rules for the direction of the mind (L. J. Lafleur, Trans.). Indianapolis, IN: Bobbs-Merrill. (Original work published in 1701) 
Dewey, J. (1933). Philosophy's search for the immutable. The quest for certainty. Retrieved from http://www.marxists.org/reference/subject/philosophy/works/us/dewey/htm.

Dewey, J. (1966). Democracy and education. New York, NY: Free Press.

Dickens, C. (1967) Hard times. New York, NY: Penguin.

Earl, L. M. (1999). Assessment and accountability in education: Improvement or surveillance? Education Canada, 39(3), 4-6 \& 47.

Earl, L. M. (1995). Assessment and accountability in education in Ontario." Canadian Journal of Education, 20(1), 45-55.

Elbow, P. (1986). Embracing contraries: Explorations in learning and teaching. New York, NY: Oxford UP.

Elbow, P. (1994). Will the virtues of portfolios blind us to their potential dangers? In L. Black, D. A. Daiker, J. Sommers, and G.I Stygall (Eds.), New directions in portfolios: Reflective practice, critical theory, and large-scale scoring (pp. 40-55). Portsmouth, NH: Boynton/Cook.

Elbow, P. (1996). Writing assessment: Do it better, do it less." In E. M. White, W. D. Lutz, \& S. Kamusikiri (Eds.), Assessment of writing: Politics, policies, practices (pp.120-34). New York, NY: MLA.

Elbow, P., \& Belanoff, P. (1997). Reflections on an explosion: Portfolios in the 90's and beyond. In K. B. Yancy, \& I. Weiser (Eds.), Situating portfolios: Four perspectives (pp. 21-33). Logan, UT: Utah UP.

Engemann, J. F., \& Gallagher, T. (2006). The conundrum of classroom writing assessment. Brock Education, 15(2), 33-44.

Fagan, L. P. (1995). Performance accountability in the Newfoundland school system. Canadian Journal of Education, 20(1), 65-76.

Franklin, Benjamin. (2010). Proposals relating to the education of youth in Pennsylvania. Retrieved from http://explorepahistory.com/ odocument.php?docld=578, University of Pennsylvania Archives.

Freeman, M., de Marrais, K., Preissle, J., Roulston, K., \&St. Pierre, E. A. (2007). Standards of evidence in qualitative research: An incitement to discourse. Educational Researcher, 36(1) 25-32.

Foucault, M. (1973). The order of things: An archaeology of the human sciences. New York, NY: Vintage. (Original work published in 1966) 
Gadamer, H G. (1990). Truth and method (J. Weinsheimer, \& D.G. Marshall, Trans.). $\left(2^{\text {nd }}\right.$ rev. ed.). New York, NY: Continuum. (Original work published in 1960)

Giddens, A. (1990). The consequences of modernity. Stanford, CA: Stanford UP.

Grassi, E. (1983). Heidegger and the question of renaissance humanism (U. Hemel, \& J. M Krois, Trans.). Binghamton, NY: Center for Medieval and Early Renaissance Studies.

Grassi, E. (2001). Rhetoric as philosophy: The humanist tradition (J. M. Krois \& A. Azodi, Trans.). Carbondale, IL: Southern Illinois UP.

Habermas, J. (1971). Knowledge and human interests (J. J. Shapiro, Trans.). Boston, MA: Beacon. (Original work published in 1968)

Hall, S. (1987 June). Gramsci and us. Marxism today, 16-21.

Hechinger, F. M. (2003). Schools for teenagers: A historic dilemma. Teachers College Record. 174, 1-14. New York, NY: Columbia University Web. 12.23.03.

Heidegger, M. (1996). Being and time: A translation of Sein und Zeit (J. Stambaugh, Trans.). Albany, NY: New York UP. (Original work published in 1927)

Hollinger, R. (1984). Toward a hermeneutical approach to education. University of Dayton Review, 17(1), 11-20.

Horkheimer, M. \& T. W. Adorno. (1972). Dialectic of enlightenment (J. Cumming, Trans.). New York, NY: Herder and Herder. (Original work published in 1944)

Hunter, D. M., R. M. Jones, \& B. S. Randhawa. (1996). The use of holistic versus analytic scoring for large-scale assessment of writing." The Canadian Journal of Program Evaluation, 11(2), 61-85.

Huot, B. (1996). Toward a new theory of writing assessment. CCC, 47(4), 549-66.

Huot, B. (2002). (Re) Articulating writing assessment for teaching and learning. Logan: Utah UP,

Lather, P. (1993). Fertile obsession: Validity after poststructuralism. Sociological Quarterly, 34(4), 673-93.

Lather, P. (2004). This IS your father's paradigm: Government intrusion and the case of qualitative research in education. Qualitative Inquiry, 10(1), 15-34. 
Lather, P. (2006). Foucauldian scientificity: Rethinking the nexus of qualitative research and educational policy. International Journal of Qualitative Studies in Education, 19(6), 783-91.

Lincoln, Y. S (1990). The making of a constructivist: A remembrance of transformations past. In E. G. Guba, (Ed.), The paradigm dialog (pp. 67-87). Newbury Park, CA: Sage.

Lincoln, Y. S. \& Cannella, G. S. (2004). "Dangerous discourses: Methodological conservatism and governmental regimes of truth." Qualitative Inquiry, 10(1), 514.

Linn, R. L., Baker, E. L., \& Dunbar, S. B. (1991). Complex, performance based assessment: Expectations and validation criteria. Educational Researcher, 20, $15-21$.

Lynne, Patricia. (2004). Coming to terms: A theory of writing assessment. Logan, UT: Utah State UP.

Maxwell, J. A. (2004). Reemergent scientism, postmodernism, and dialogue across differences. Qualitative Inquiry, 10(1), 35-41.

McCloskey, D. N. (1985). The rhetoric of economics. Madison, WI: Wisconsin UP.

McEwen, N. (1995a). Accountability in education in Canada. Canadian Journal of Education, 20(1), 1-17.

McEwen, N. (1995b). Accountability in education in Alberta. Canadian Journal of Education, 20(1), 27-44.

McEwen, N., Fagan, L. P., Earl, L. M., Hodgkinson, D., \& Maheu, R. (1995). Reflections and clarifications." Canadian Journal of Education, 20(1), 99-107.

Moss, P. A. (1994). Can there be validity without reliability? Educational Researcher, 23(2), 5-12.

Moss, P. A., Beck, J. S., Matson B., Muchmore, J., Steele, D., \& Taylor, C. (1992). Portfolios, accountability, and an interpretative approach to validity. Educational measurement: Issues and practice, 11(3), 12-21.

Nagy, P. (1995). Accountability in a broader context. Canadian Journal of Education, 20(1), 92-98.

Nietzsche, F. (1979). Philosophy and truth: Selections from Nietzsche's notebooks of the early 1870's. (D. Breazeale, Ed. \& Trans.). New Jersey: Humanities. 
Nietzsche, F. (2001). The gay science. (J. Nauckhoff, Trans.). New York, NY: Cambridge UP. (Original work published in 1882)

Peterson, S. S. and J. McClay. (2010). Assessing and providing feedback for student writing in Canadian classrooms. Assessing Writing. Elsevier. 9 June.05.003. Web. In Press, Corrected Proof, Available online.

Petruzzi, A. (2008). Articulating a hermeneutic theory of writing assessment. Assessing Writing, 13, 219-42.

Polanyi, M. (1964). Personal knowledge: Towards a post-critical philosophy. New York, NY: Harper.

Reese, W. J. (1995). The origins of the American high school. New Haven, CT: Yale UP.

Rorty, R. (1979). Philosophy and the mirror of nature. Princeton, NY, Princeton UP.

Rorty, R. (1982). Consequences of pragmatism. Minneapolis, MN: Minnesota UP.

Rorty, R. (1991). Pragmatism without method. Objectivity, relativism, and truth: Philosophical papers (pp. 63-77), (Vol. 1). New York, NY: Cambridge UP.

Rorty, R. (1995). Dewey between Hegel and Darwin." In H. J. Saatkamp, (Ed.), Rorty and pragmatism (pp. 1-15). Nashville, TN: Vanderbilt UP.

Ruccio, D. F., \& Amariglio, J. (2003). Postmodern moments in modern economics. Princeton, NJ: Princeton UP.

Sizer, T. R. (1992). Horace's school: Redesigning the American high school. Boston, MA: Houghton.

Toulmin, S. (1982). The construal of Reality: Criticism in modern and postmodern science. Critical Inquiry, 9, 93-111.

Vattimo, G. (1991). The end of modernity: Nihilism and hermeneutics in postmodern culture. J. (R. Snyder, Trans.). Baltimore, MD: Johns Hopkins UP. (Original work published in 1985)

Vattimo, G. (1997). Beyond interpretation: The meaning of hermeneutics for philosophy. (D. Webb, Trans.). Stanford, CA: Stanford UP. (Original work published in 1994)

Volante, L., \& S. Ben Jaafar. (2008). Profiles of education assessment systems worldwide. Assessment in Education: Principles, Policy, \& Practice, 15(2), 20110. 
Vico, G. (1990). On the study of methods of our time. (E. Gianturco, Trans.). Ithaca, NY: Cornell UP. (Original work published in 1709)

White, E. M. (1994). Portfolios as an assessment concept. In L. Black, D. A. Daiker, J. Sommers, \& G. Stygall (Eds.), New directions in portfolio assessment (pp. 5667). Portsmouth, NH: Heinemann.

White, E. M. (1996). Power and agenda setting in writing assessment. In E. M. White, W. D. Lutz, \& S. Kamusikiri (Eds.), Assessment of writing: Politics, policies, practice (pp. 9-24). New York, NY: MLA.

Williamson, M. (2009). The worship of efficiency: Untangling theoretical and practical considerations in writing assessment." In B. Huot \& P. O'Neill (Eds.), Assessing writing: A critical sourcebook (pp. 57-80). Boston: Bedford/St. Martins.

Yancey, K. B., \& I. Weiser. Situating portfolios: An introduction. In. K. B. Yancey \& I. Weiser (Eds.), Situating portfolios: Four perspectives (pp. 1-17). Logan, UT: Utah UP.

\section{Bio}

Anthony P. Petruzzi is Director of Writing Assessment at University of Massachusetts, Boston. In 1999, he received a J. William Fulbright Scholarship for research in philosophical hermeneutics at the Università degli Studi di Torino. His recent research uses philosophical hermeneutics to analyze rhetoric, technology, science, and assessment. His work is an interdisciplinary blend of philosophical hermeneutics, rhetorical criticism, and composition theory.

\footnotetext{
${ }^{1}$ In the essay, I use the term 'postmodernity' to categorize theories of rhetoric and philosophy that have a common axis in hermeneutics and that abandon the belief that some version of scientific method is, a priori, a requirement for meaningful educational assessment. I simplify the concept of modernity by focusing its belief in the primacy of science and its claim that quantitative reasoning grounds knowledge on objective and certain truths. The contemporary debate has spurred a counter-argument against postmodernity that reasserts the need for 'objective' or rigorous 'standards of evidence' (i.e. quantitative models of research), which dominate the accountability movement (Lincoln \& Cannella, 2004, pp. 5-6; Lather, 2004; and, Lynne on objectivity and assessment (pp. $17 \mathrm{ff})$.

${ }^{2}$ Also see D. M. Hunter et al. (1996) and J. F. Engemann \& T. Gallagher (2006).

${ }^{3}$ Martin Heidegger's (1996) analysis of being-in-the-world focuses on general and public moods as a way of we attune ourselves to our environing worlds: "attunement" is "what is most familiar and an everyday kind of thing: mood, being in a mood." Moods are "fundamental" to how we understand and act because we are "always already in a mood" (p. 126). Because dispositions are always already there, human existence always dwells in transparent everyday moods. We are "thrown" without choice into particular dispositions according to historical circumstances and, for the most part, we evade what is disclosed - as we do with scientism. Heidegger notes, "in the evasion itself the there is something disclosed" (author's emphasis; p. 127).

4 Traditional writing assessment assumes Dilthey's distinction between natural and social sciences (Petruzzi, 2008, pp. 2119-220) to summon and transfer its social and intellectual authority to itself as a
} 
'human science' to associate itself with "the modern episteme." As Lather (2006) notes, Foucault "is most useful in seeing how, in the continuation of the science wars, the line between a narrowly defined scientism and a more capacious scientificity of disciplined inquiry remains very much at issue" (p. 785). Foucault (1973) argues, human sciences "are not sciences at all. The configuration that defines their positivity and gives them their roots in the modern episteme at the same time makes it impossible for them to be sciences; and if it is asked why they assume the title [... it is because] they summon and receive the transference of models borrowed from the sciences" (p. 366).

${ }^{5}$ Elsewhere, I argue that definitions of "performance assessments" rarely stipulate a cognitively complex mode of assessment that evokes and evaluates higher order habits of mind (2008 234-36 \& note 10).

${ }^{6}$ The Canadian constitution requires the provinces to administer education, so every province determines its own way of addressing accountability; and, each province "administers some form of mandated largescale educational assessment." Additionally, there is a "national assessment programme, the School Achievement Indicators Programme that is conducted in all Canadian provinces" (Volante \& Jaafar, 2008, pp. 201-03; also see Peterson \& McClay, 2010, p. 2).

${ }^{7}$ Elbow and Belanoff (1997) note that accreditation agencies and school administrators have "turned more and more to outside testing, psychometricians, and large testing agencies to ascertain and validate student learning in order to evaluate the effectiveness of teachers and programs. People began to believe that without an outside-derived number and a grade it was impossible to trust that any learning had taken place" (emphasis added; p. 23). With the exception of Earl, the four anchor essays dwell in a culture that presumes scientism, and the attendant belief that only 'objective' evaluations are 'valid.'

${ }^{8}$ Benjamin Franklin (2010), in 1747, articulates the idea that education cultivates "profitable" seeds (p. 1). For Franklin, education is simplistically pragmatic - teaching "every thing that is useful" (p. 2). Education helps middle class workers to "improve his trade or handicraft" and to "understand many commodities" ( $p$. 2 ); it leads to commercial success and profit supporting the status and power of middle and upper class families in the marketplace. North American public high schools in the $18^{\text {th }}$ and $19^{\text {th }}$ century were designed to provide merchants with employees who had the practical literacy skills for commerce. William J. Reese (1995) states, "colonial public schools were not created as potential avenues of opportunity for poorer boys or any girls or people of color. Education largely confirmed one's status or enabled young men with family advantages to gain the skills to compete more favorably in a world of supply and demand" (p. 6).

${ }_{9}^{9}$ Habermas notes we delude ourselves into thinking that quantitative analysis shows "a self-subsistent world of facts structured in a law-like manner; it thus conceals the a priori constitution of these facts" (69).

10 As Huot (2002) notes, quantitative writing assessment is "built upon psychometrics, a statistical apparatus devised for use in the social and hard sciences. Mathematics [...] was conceived as the 'language' of an empirical methodology that would assist in the discovery of fundamental laws governing human behavior" (p. 83).

${ }^{11}$ Michael Polyani (1964) states, "the prevailing conception of science, based on the disjunction of subjectivity and objectivity, seeks — and must seek at all costs - to eliminate from science [...] passionate, personal, human appraisals of theories, or least to minimize their function" (p. 15). According to Polyani, this conception of science stems "from a craving rooted in the very depths of our culture" ( $p$. 16). In addition to the assumption that inquiry must evade weak, "subjective," or emotional reasoning because it taints objectivity.

12 In Philosophy and Truth, Nietzsche (1979) works through different lines of argument than Dewey, but he identifies and critiques the same affective drive to equate truth and Being (pp. 83-5). Nietzsche explores our affective relationship to various concepts of truth, which frame the way we understand truth.

${ }_{13}$ Donald N. McCloskey (1985) in his analysis of the rhetoric of economics, calls this kind of pervasive thinking the "received view." For McCloskey, "the program of Descartes" frames and models much more than scientific knowledge; therefore, "to emphasize its pervasiveness in modern thinking," we should call this official and unofficial attitude "modernism" (p. 5).

${ }^{14}$ Earl makes the same basic argument with more specificity regarding the problems inherent with calculative reasoning (1999 6).

${ }^{15}$ This is exactly what Brownlee argues is the reductionist approach to accountability: "subdividing the situation into so-called manageable parts to study and analyze" (p. 80). 
${ }^{16}$ Also see Grassi (1983), pp. 9-18.

${ }_{17}^{17}$ Also see Grassi (2001), pp. 35-40.

${ }^{18}$ Hannah Arendt (1978) concurs with Vico arguing that Descartes imagines a worldless cogito that is bodiless and, since one's essential self doesn't dwell in the world, we can reduce that which is not-I to an object to be measured (pp. 46-9).

${ }^{19}$ While Habermas defends enlightenment rationality from critics, like Horkheimer and Adorno, he criticizes, what Stuart Hall (1987) calls "regressive" modernism (p. 17) and its resultant scientism.

${ }^{20}$ See Broad (1994). Elbow (1996) notes, calculative reasoning is a cultural disposition that functions like the power of gravity to hold assessment within the orbit of quantitative methods: "in our culture, we seem to suffer from a pervasive, popular assumption that evaluation isn't trustworthy, hardheaded, or honest unless it consists of a single number. As professionals, therefore, we need to convince people that evaluation isn't trustworthy unless it avoids the distortion of a single number by distinguishing strengths and weaknesses in the same performance or portfolio" (author's emphasis; p. 125).

${ }^{21}$ Kathleen Blake Yancey and Irwin Weiser (1997) note that writing portfolios emerged as "a creative response" to demands for accountability (p. 1). They introduce the various essays in terms of whether they are "working more quantitatively" (p. 7) or "more [qualitatively]" saying that they share the general concern that research must "validate practice." While they call for research that "is more interpretive in nature," like Elbow, they frame their call to "refute what has come before" within the discourse of quantitative research and its key term: validity (emphasis added; p. 13).

${ }_{22}$ Elbow (1986) emphasizes the "conditionality of method" (p. 270) and the primacy of argumentative reasoning, rather than objectivity, yet he continues to see assessment in terms of a modernist epistemology. Elbow argues that we need epistemology to "decide which knowledge is most trustworthy, even if it is not certain" (p. 257). Elbow wants to arrive at a hermeneutic result, i.e. one that ends with interpretation. But, he seems to support the modern notion that epistemology can produce accurate representations of the order of things (Rorty, 1979, pp. 315ff).

${ }^{23}$ Denzin and Lincoln (2003) argue that qualitative educational assessment is framed by scientific methodology: "[h]istorically qualitative research was defined within the positivist paradigm, where qualitative researchers attempted to do good positivist research with less rigorous methods and procedures" (p. 14). Lincoln (1990) argues that constructivists deceived themselves about accommodating scientism: "We [Constructivists] have deluded ourselves that the discourse of constructivism could resemble the discourse of [natural] science, and I and others were wrong (p. 86).

${ }^{24}$ Ruccio and Amariglio (2003) argue that modernity privileges scientism:

scientific concepts, methods, protocols, and the like are exclusively entitled to the power and privilege they have achieved with modernization. If the growth of scientific knowledge is the key accomplishment of the past three centuries in the West, it has been accompanied by an elaborate philosophical defense of a variety of exclusionary practices by which those deemed to be untrained in or unreceptive to such science are shunted aside or even denied opportunities to speak (since they are considered to be the voice of unreason). (emphasis added; p. 42)

${ }^{25}$ The Canadian debate includes implied threats to "privatize" schools that do not provide scientific accountability data (McEwen et al., 1995, p. 101 \& p. 103). Those under the sway of calculative reasoning have not been persuaded that pure objectivity is not possible, that industrial and business methodology is not transferable education, and that knowledge is not a thing, a material object to be measured and possessed.

${ }^{26}$ White (1996) makes the "pragmatic" case this way: "I do not think the nation can or will allow writing teachers to set the entire agenda for writing assessment- any more than it will allow physicians to determine health-care policy" (p. 15).

${ }^{27}$ Anson (2008) laments compositionists turn from quantitative to qualitative research: "inquiry into the actualities of a situation, inquiry that is explicitly enough systematized in sampling, execution, and analysis to be replicated [...] and factually enough supported to be verified" (p. 21). 